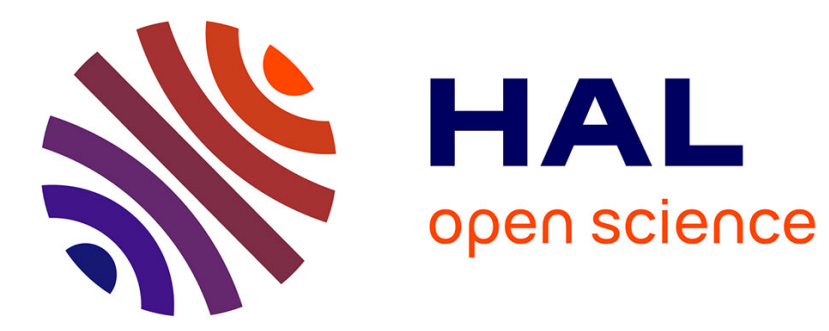

\title{
KINETICS OF THE CHEMICAL VAPOR DEPOSITION OF SILICON NITRIDE-FROM Si(CH3)4/ NH3/H2 GAS MIXTURES
}

\author{
N. Roels, T. Lecointe, René Guinebretière, J. Desmaison
}

\section{- To cite this version:}

N. Roels, T. Lecointe, René Guinebretière, J. Desmaison. KINETICS OF THE CHEMICAL VAPOR DEPOSITION OF SILICON NITRIDE-FROM Si(CH3)4/ NH3/H2 GAS MIXTURES. Journal de Physique Colloques, 1989, 50 (C5), pp.C5-435-C5-444. 10.1051/jphyscol:1989555 。 jpa-00229585

\section{HAL Id: jpa-00229585 https://hal.science/jpa-00229585}

Submitted on 1 Jan 1989

HAL is a multi-disciplinary open access archive for the deposit and dissemination of scientific research documents, whether they are published or not. The documents may come from teaching and research institutions in France or abroad, or from public or private research centers.
L'archive ouverte pluridisciplinaire HAL, est destinée au dépôt et à la diffusion de documents scientifiques de niveau recherche, publiés ou non, émanant des établissements d'enseignement et de recherche français ou étrangers, des laboratoires publics ou privés. 
JOURNAL DE PHYSIQUE

Colloque C5, supplément au $\mathrm{n}^{\circ} 5$, Tome 50, mai 1989

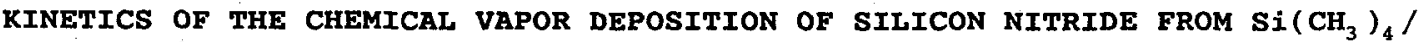 $\mathrm{NH}_{3} / \mathrm{H}_{2}$ GAS MIXTURES
}

\author{
N. ROELS, T. LECOINTE, R. GUINEBRETIERE and J. DESMAISON \\ Laboratoire de Céramiques Nouvelles, CNRS UA-320, Université de \\ Limoges, 123, avenue A. Thomas, F-87060 Limoges, France
}

\begin{abstract}
Résumé - L'étude de la cinétique de dépôt chimique en phase vapeur de $\mathrm{Si}_{3} \mathrm{~N}_{4}$ sur substrat graphite par pyrolyse de mélanges tetraméthylsilane-ammoniac-hydrogene est conduite dans un four a parois chaudes sous pression réduite. Les conditions experimentales permettant un contrôle de la vitesse de dépôt par la réaction de surface sont définies. La structure et la composition des dépots correspondants sont également précisées.

Abstract - The kinetic study of the chemical vapour deposition of $\mathrm{Si}_{3} \mathrm{~N}_{4}$ on graphite substrates by low pressure pyrolysis of tetramethylsilane-ammonia-hydrogen mixtures is conducted in a hot wall reactor. The experimental conditions allowing the control of the deposition rate by the surface chemical reaction are defined. The structure and composition of the corresponding films are described.
\end{abstract}

\section{1 - INTRODUCTION}

Chemical vapour deposition (CVD) can produce non-oxide ceramics with properties that cannot be obtained in monolithics. For example, the product of CVD may be stronger, harder and more corrosion, oxidation or erosion-resistant than the same compound consolidated by sintering $11,2 /$. The improved properties of coatings. are attributable to fine grain size, high density and purity. Hence a major advantage of CVD processes is the ability to control the microstucture and by extension to optimize the properties of the coating.

The purpose of this work has been to detail the influence of the experimental parameters on the deposition rate, microstucture and composition of silicon nitride, obtained from tetramethylsilane (TMS) and ammonia, in order to find out the optimal conditions for protection against oxidation of porous reaction-bonded silicon nitride (RBSN) substrates.

\section{2 - EXPERTMENTAL}

The $\mathrm{Si}\left(\mathrm{CH}_{3}\right)_{4} / \mathrm{NH}_{3}$ system was chosen because TMS is an organometallic precursor easy to handle since it is not corrosive, does not readily hydrolyze and has a high vapour pressure at ambient temperature. Also, previous experimental and thermodynamic investigations of this system $|3-12|$, have shown the existence of a wide deposition domain for $\mathrm{Si}_{3} \mathrm{~N}_{4}$.

The vertical hot-wall type low pressure CVD reactor used is shown schematically in Fig. 1. The reaction chamber was a graphite tube $88 \mathrm{~mm}$ high and $40 \mathrm{~mm}$ in diameter inductively heated at $30 \mathrm{kHz}$. The reactor and the inductor are both located in a water cooled stainless steel vacuum tight chamber $400 \mathrm{~mm}$ high and $350 \mathrm{~mm}$ in diameter. The low frequency used prevents plasma-generation at low pressures. The reactant gases TMS, $\mathrm{NH}_{3}, \mathrm{H}_{2}$ were metered through mass flowmeters and the gas mixture was fed to the top of the reactor through a quartz injector $8 \mathrm{~mm}$ in diameter. The vacuum pump was protected against solid or gaseous reaction by-products by a powder filter and a liquid-nitrogen cold trap. The temperature was controlled using a Pt-(Pt-10\% Rh) thermocouple sheathed in a quartz tube inserted in the graphite sample holder. The substrates were graphite disks $10 \mathrm{~mm}$ in diameter and $5 \mathrm{~mm}$ high.

Deposition rate was determined by weight increase. X-ray diffraction (XRD) was used to identify the coatings. The morphology was characterized using optical or scanning electron microscopy (SEM). The composition of the deposits was checked by electron probe microanalysis (EPM), Auger electron spectroscopy (AES) and electron spectroscopy for chemical analysis (ESCA).

\section{3 - RESULTS AND DISCUSSION}

\section{1 - Preliminary studies}

In previous studies $|3-12|$ it has been shown that four condensed phases ( $\mathrm{Si}, \mathrm{C}, \mathrm{SiC}, \mathrm{Si} \mathrm{N}_{4}$ ) are Iikely to deposit. However, it is possible to obtain pure silicon nitride with an exçess of ammonia $\left(\mathrm{N} / \mathrm{Si}>3\right.$ ) over a wide temperature range $\left(800-1500^{\circ} \mathrm{C}\right)$. 


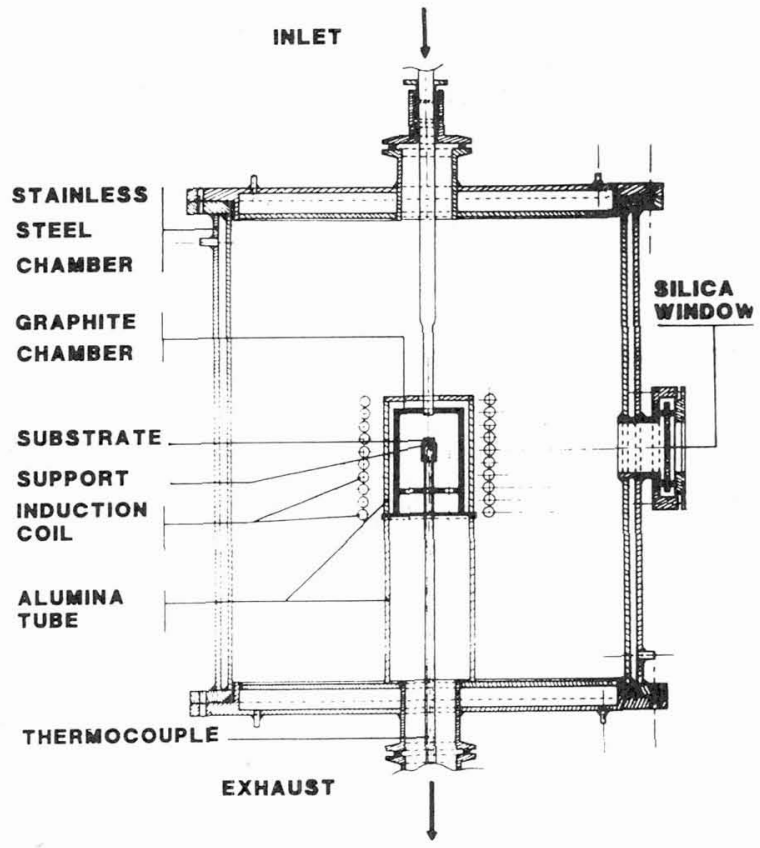

Fig. 1 - Schematic diagram of the reaction chamber of the CVD apparatus

Table I - Operating condition of interest in this study
Table II - Range of each parameter explored in the experimental planning

\begin{tabular}{|c|c|c|}
\cline { 2 - 3 } & Mininu & Maximua \\
\hline Temperature ("C) & 900 & 1300 \\
\hline Pressure (Torr) & 4 & 10 \\
\hline N/\$1 ratio & 1 & 12 \\
\hline (NH3+ThS) Flow rate $(1 / \mathrm{h})$ & 1 & 2,5 \\
\hline hydrogen flow rate $(1 / \mathrm{h})$ & 50 & 100 \\
\hline Time $(\mathrm{h})$ &, 5 & 4 \\
\hline
\end{tabular}

\begin{tabular}{|c|c|c|}
\cline { 2 - 3 } & Minimun & Maxinu \\
\hline Temperature $\left({ }^{\circ} \mathrm{C}\right)$ & 1000 & 1200 \\
\hline Pressure (Torr) & 4 & 10 \\
\hline N/SI Ratio & 5 & 10 \\
\hline (MH3+THS) flow rate $(1 / \mathrm{h})$ & 1,5 & 2 \\
\hline hydrogen flow rate $(1 / \mathrm{h})$ & 80 & 100 \\
\hline
\end{tabular}


The experimental domain explored in this work is presented in Table I.

The XRD analysis reveals the exclusive presence of $\alpha-S i_{3} \mathrm{~N}_{4}$ as a crystalline phase at $1250^{\circ} \mathrm{C}$ and above.

In the amorphous region, the AES, ESCA and quantitative electron microprobe analyses indicate the predominant presence of $\mathrm{Si}_{3} \mathrm{~N}_{4}$ plus smal1 amounts of oxygen (4 wt $\%$ ) and carbon (5-7 wt $\%)$. In the crystalline region, the oxygen content does not change while the carbon content decreases down to 2 wt $\%$.

The SEM analysis of the corresponding coatings show that with increasing temperature and decreasing pressure, the microstructure varies from dome-like cone to fine column. An increase of the $\mathrm{N} / \mathrm{Si}$ ratio results in a noticeable decrease of the size of the cones.

\section{2 - Experimental design}

In order to determine the main parameters controlling the vapour deposition rate (R) of silicon nitride, we have used a fractional factorial design $2^{n-1}$. A preliminary "screening" of these parameters has allowed us to select those having a significant influence on the deposition process $/ 13 /$. These five factors $(n=5)$, temperature (T), total pressure (P), $N / S i$ ratio $(N / S i)$, total flow rate of the reactants TMS and NH3 $\left(D_{R}\right)$, flow rate of hydrogen $\left(D_{H}\right)$, and their domain of variation, are given in table II. Such a method presents the great advantage of reducing the number of experiments to only 16 . It leads to a description of the response parameter (deposition rate $\mathrm{R}\left(\mathrm{mg} \cdot \mathrm{cm}^{-2} \cdot \mathrm{h}^{-1}\right)$ ) by a polynomial function of these five factors and of their product :

$R=1,63+1,43 \cdot T+0,71 \cdot P+0,64 \cdot T \cdot P+0,40 \cdot P \cdot D_{H}+0,39 \cdot T \cdot P \cdot D_{H}+0,35 \cdot T \cdot P \cdot N / S i+$ $0,29 \cdot \mathrm{P} \cdot \mathrm{N} / \mathrm{Si}-0,11 \cdot \mathrm{N} / \mathrm{Si}+0,11 \cdot \mathrm{P} \cdot \mathrm{D}_{\mathrm{R}}-0,10 \cdot \mathrm{T} \cdot \mathrm{D}_{\mathrm{R}}+0,06 \cdot \mathrm{T} \cdot \mathrm{P} \cdot \mathrm{D}_{\mathrm{R}}-0.03 \cdot \mathrm{D}_{\mathrm{R}}+0,03 \cdot \mathrm{T} \cdot \mathrm{D}_{\mathrm{H}}-$ $0,02 \cdot \mathrm{T} \cdot \mathrm{N} / \mathrm{Si}+0,02 \cdot \mathrm{D}_{\mathrm{H}}$

A reproducibility test conducted in the center of the experimental domain gives a relative deviation of $5 \%$. An analysis of the variance $/ 13 /$, based on the classification by decreasing order of the coefficients of the polynomial expression and on the selection of the only coefficients satisfying the significance level of 0.05 (test of SNEDECOR) leads to the expression :

$\underset{0,29 \cdot \mathrm{P} \cdot \mathrm{N} / \mathrm{Si}}{\mathrm{R}=1,63}+1,43 \cdot \mathrm{T}+0,71 \cdot \mathrm{P}+0,54 \cdot \mathrm{T} \cdot \mathrm{P}+0,40 \cdot \mathrm{P} \cdot \mathrm{D}_{\mathrm{K}}+0,39 \cdot \mathrm{T} \cdot \mathrm{P} \cdot \mathrm{D}_{\mathrm{H}}+0,35 \cdot \mathrm{T} \cdot \mathrm{P} \cdot \mathrm{N} / \mathrm{Si}+$

The main factors controlling the reaction rate are the temperature and the total pressure. Two other factors $\left(D_{\mathrm{H}}\right.$ and $\mathrm{N} / \mathrm{Si}$ ) appear in this expression, but in interaction with the two first ones. On the contrary the parameter $D_{R}$ is absent but it may be due to the small extent of the variation domain of this parameter $(\max / \min =1.3)$.

\section{3 - Kinetics}

A complementary study of the influence of CVD parameters (deposition time, deposition temperature, total flow rate and partial pressure of reactant gases) on the deposition rate of $\mathrm{Si}_{3} \mathrm{~N}_{4}$ was conducted in order to locate the regions where the limiting process is respectively the surface reaction and the mass transport. Such a knowledge is very important to improve the deposition technology and to obtain uniform deposition.

\subsection{1 - Deposition time}

The weight of the samples increases linearly with deposition time as shown in Fig. 2. This means that the reaction is carried out under the steady state and that the deposition $R$ rate can be directly derived from the slope of the straight lines.

\section{3 .2 - Deposition temperature}

In agreenent with the experimental design results, Fig. 3 shows that at a given total pressure the deposition rate increases strongly with temperature. The Arrhenius plot of Fig. 4 reveals the existence of a deviation from a straight line above $1200^{\circ} \mathrm{C}$. In the Iower temperature range, the apparent activation energy $\mathrm{E}$ is close to $315 \mathrm{~kJ} / \mathrm{mol}$.

$$
\mathrm{R}=\text { constant. } \exp (-315 / \mathrm{RT}) \quad(\mathrm{T}<1473 \mathrm{~K})
$$

In the higher temperature range, the activation energy decreases and its value is a function of pressure $(80<\mathrm{E}<190 \mathrm{~kJ} / \mathrm{mol})$. These results suggest a change from surface reaction control to mass transport control of the deposition process as temperature increases. 


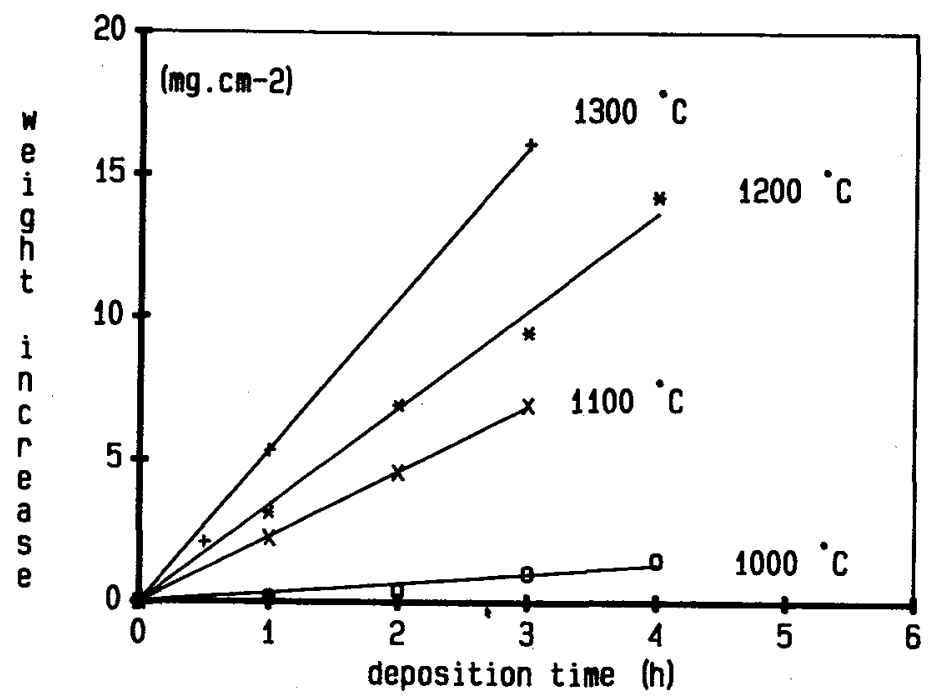

Fig. 2 - Weight change dependency on time

(N/Si=10, $D_{R}=1,51 / h, D_{H}=801 / h, P=10$ Torr)
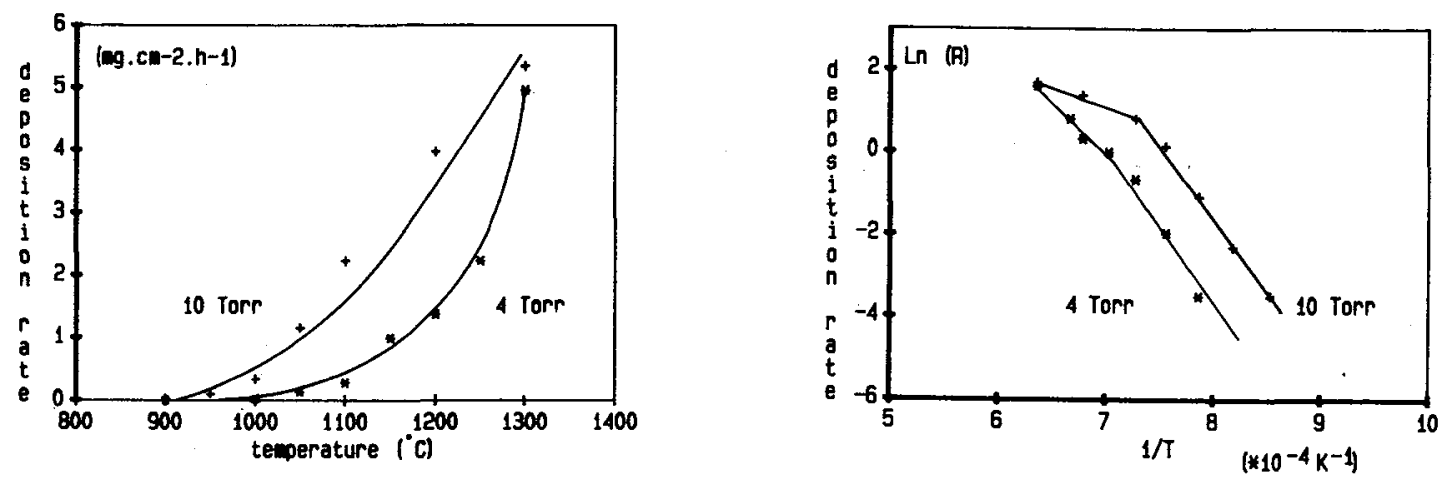

Fig. 3 - Dependence of silicon

Fig. 4 - Arrhenius plot

nitride deposition rate for the CVD deposition

on temperature rate as fonction of temperature

$\left(\mathrm{N} / \mathrm{Si}=10, \mathrm{D}_{\mathrm{R}}=1,5 \mathrm{I} / \mathrm{h}, \mathrm{D}_{\mathrm{H}}=801 / \mathrm{h}\right)$ 


\subsection{3 - Total pressure}

The influence of the total pressure is illustrated in Figs. 3 to 5 . At constant temperature, $R$ globally increases with pressure and the pressure dependence of the deposition rate increases with temperature. However, at the higher temperatures, a gradual decrease of $R$ is observed above a critical value of $P$ (Fig. 5). This decrease is probably due to the depletion of reactants caused by the homogeneous nucleation whose rate increases with the total pressure and the temperature.

\section{3 .4 - Total flow rate of reactants $\left(\mathrm{NH}_{3}+\mathrm{TMS}\right)$}

Fig. 6 represent the dependence of $R$ on the total flow rate of reactants $\left(D_{R}\right)$ at a total pressure $\mathrm{P}=4$ Torr. Almost no dependence is observed at $1000^{\circ} \mathrm{C}$. At 1100 and $1200^{\circ} \mathrm{C}$, the deposition rate increases with $D_{R}$ up to 1.5 or $21 /$ h and then it saturates with a further increase in the total flow rate. These results explain why $D_{R}$ does not appear in the $f$ inal expression of the experimental planning. At $1300^{\circ} \mathrm{C}, \mathrm{R}$ passes through a maximum.

This phenomenon is due to the change of the deposition mechanism. An increase in growth with input flow rate indicates mass transport limitations /14-16/. Therefore, the deposition rate is controlled by the mass transport at low total flow rates $\left(D_{R}<21 / \mathrm{h}\right)$ and high temperatures $\left(T>1200^{\circ} \mathrm{C}\right)$. On the reverse, it is controlled by the surface reaction at high total flow rates $\left(D_{R}>1.5 \mathrm{I} / \mathrm{h}\right)$ and low temperatures $\left(T<1300^{\circ} \mathrm{C}\right)$.

The decrease in growth with input flow rate observed at $1300^{\circ} \mathrm{C}$ for high values of $D_{R}(>1.5$ $1 / \mathrm{h}$ ) may be attributed to the contribution of homogeneous nucleation. Such a phenomenon has been already observed in the case of the deposition of silicon nitride from silane-ammonia mixtures $|17|$.

3.3 .5 - Partial pressures of TMS and $\mathrm{NH}_{3}$

Figures $7 \mathrm{~A}$ and $\mathrm{7B}$ present the effect of the partial pressures of TMS and $\mathrm{NH}_{3}$ respectively on the deposition rate. The study was conducted under experimental conditions where the surface chemical reaction is rate controlling and the homogeneous reaction is negligible $\left(\mathrm{T}<1200^{\circ} \mathrm{C}\right.$, $p$ close to 4 Torr). The growth rate can be described by the following empirical expression :

$$
\mathrm{R}=\text { constant.P(TMS })^{1} \cdot \mathrm{P}\left(\mathrm{NH}_{3}\right)^{0}
$$

giving the reaction orders with respect to the two partial pressures. This expression shows that $\mathrm{R}$ is independent of the concentration of $\mathrm{NH}_{3}$ while there is a linear relationship between $R$ and the concentration of TMS. In addition it reveals the independence of the exponents upon the nature of the diluent gas.

\section{3 .6 - Influence of the diluent gas}

However, Figs. 7A and $7 \mathrm{~B}$ show that at $1200^{\circ} \mathrm{C}$ and a given pressure of TMS or $\mathrm{NH}_{3} \mathrm{R}$ sligthly decreases when hydrogen is replaced by $\mathrm{N}_{2}$ or $\mathrm{Ar}$. Therefore we have studied the influence of the partial pressure of each of these gases between 1100 and $1200^{\circ} \mathrm{C}$. The results are illustrated by the Ln(R)-Ln(P) plots of Figs, $8 \mathrm{~A}, 8 \mathrm{~B}$ and $8 \mathrm{C}$. While the exponent of the corresponding power law $\left(R=\right.$ cte. $\left.P^{n}\right)$ is independent of temperature $(n=-3.15)$ in the case of $\mathrm{Ar}$ (Fig.8A), it increases with temperature when the carrier gas is $\mathrm{H}_{2}(\mathrm{Fig}$. $8 \mathrm{~B})$ or $\mathrm{N}_{2}$ (Fig. $8 \mathrm{C}$ ).

3.3 .7 - Comparison with previous studies of the kinetics of $\mathrm{Si}_{3} \mathrm{~N}_{4}$ film deposition and discussion of the reaction mechanism

The obtained results concerning TMS and $\mathrm{NH}_{3}$ are in complete agreement with those previously published for various silicon nitride film deposition processes conducted under kinetic regime control $/ 15,16 /$. When a silicon-containing compound ( $\mathrm{SiH}_{4}, \mathrm{SiH}_{2} \mathrm{Cl}_{2}, \mathrm{SiCl}_{4} \ldots$ ) is reacted with an excess of $\mathrm{NH}_{3}$, the reaction order is zero with respect to this second reactant, while it is one for the first one which acts as the limiting reagent $/ 15,16 /$. Such a behaviour may be described by the Rideal-Eley mechanism for heterogeneous deposition which assumes a reaction between a molecule $A$ adsorbed and a molecule $B$ from the gaseous phase $112,15 /$. However this does not means that the actual adsorbed phase is TMS, as suggested by the global chemical reaction :

$$
3 \mathrm{Si}\left(\mathrm{CH}_{3}\right)_{4}+4 \mathrm{NH}_{3}=\mathrm{Si}_{3} \mathrm{~N}_{4}(9)+12 \mathrm{CH}_{4}
$$

In fact, due to the thermal instability of both TMS and $\mathrm{NH}_{3}$ in the explored temperature range, it could be an intermediate compound produced by a homogeneous reaction near the 


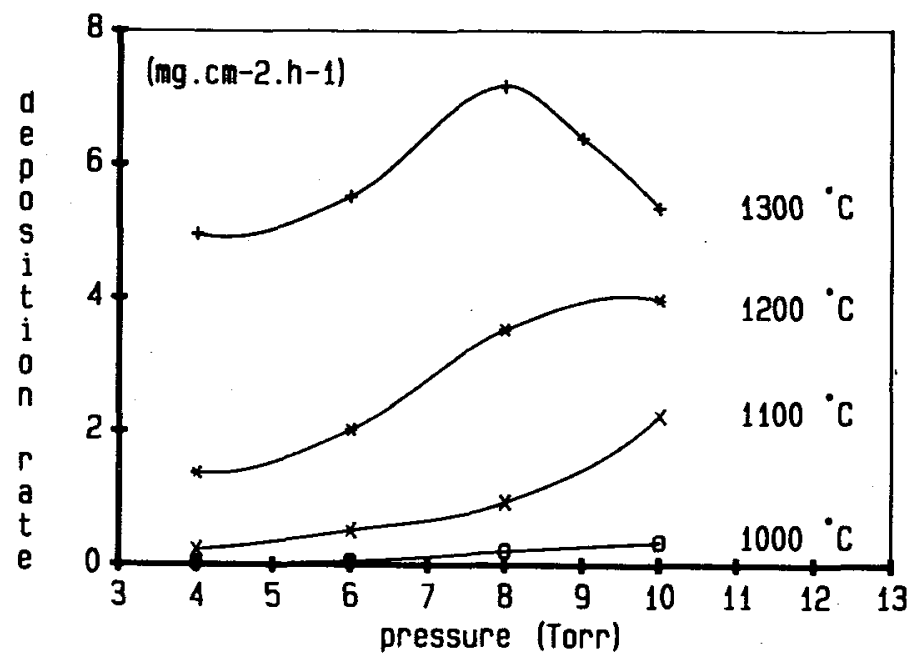

Fig. 5 - Influence of total pressure on deposition rate of silicon nitride $\left(\mathrm{N} / \mathrm{Si}=10, \mathrm{D}_{\mathrm{R}}=1,5 \mathrm{I} / \mathrm{h}, \mathrm{D}_{\mathrm{H}}=80 \mathrm{I} / \mathrm{h}\right.$ )

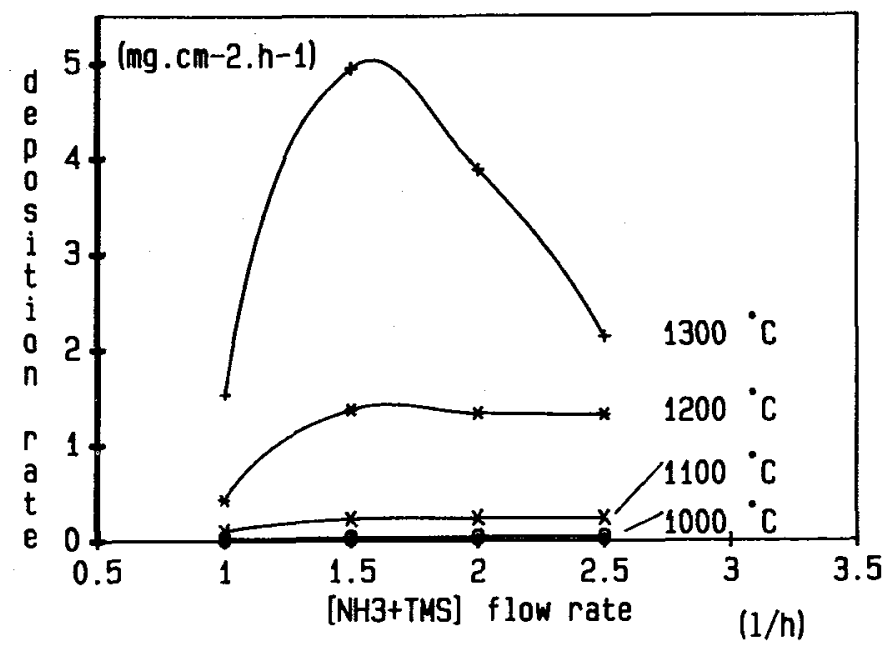

Fig. 6 - Effect of total flow rate of reactants ( $\mathrm{NH}_{3}$ +TMS) on deposition rate (N/Si=10, $\mathrm{P}=4$ Torr, $\mathrm{D}_{\mathrm{B}}=801 / \mathrm{h}$ ) 


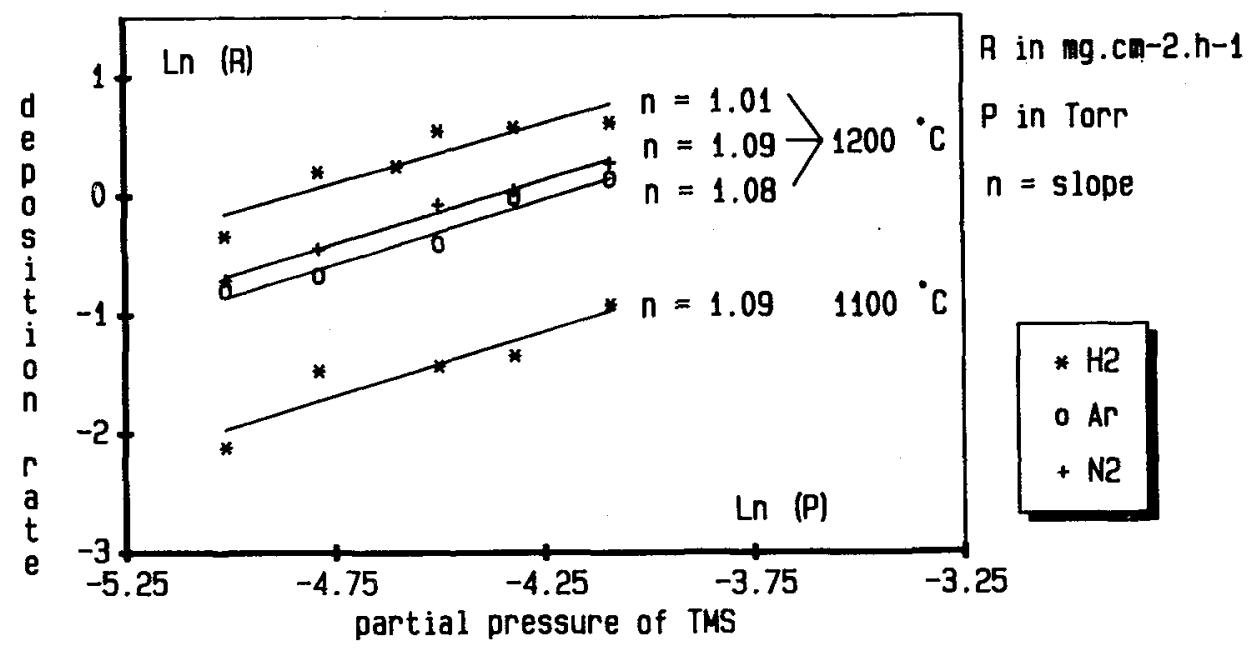

A

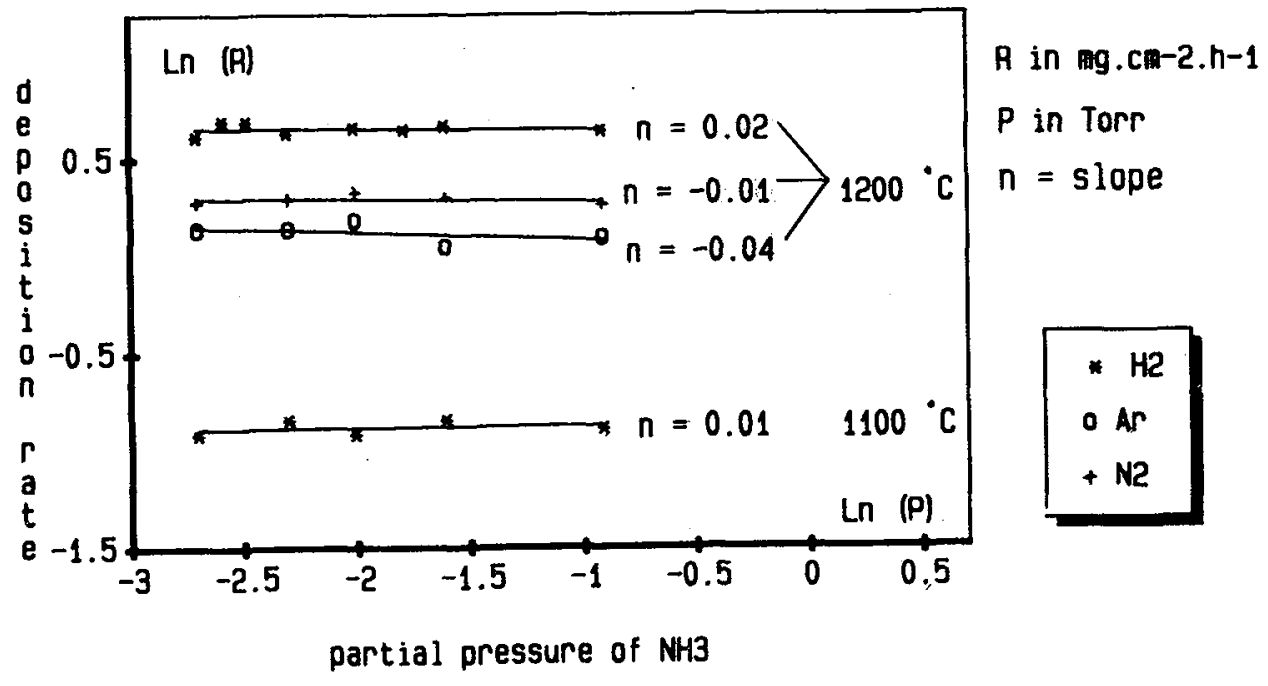

B

Fig. 7 - Growth rate dependency upon partial pressures.
$A:$ (TMS) $\quad \mathrm{P}_{\mathrm{NH} 3}=6,7 \cdot 10^{-2}$ Torr
$B:\left(\mathrm{NH}_{3}\right) \quad \mathrm{P}_{\mathrm{TMS}}=1,7 \cdot 10^{-2}$ Torr
$P_{\text {dil }}=3,77$ Torr, $D_{\text {total }}=801 / \mathrm{h}$ 


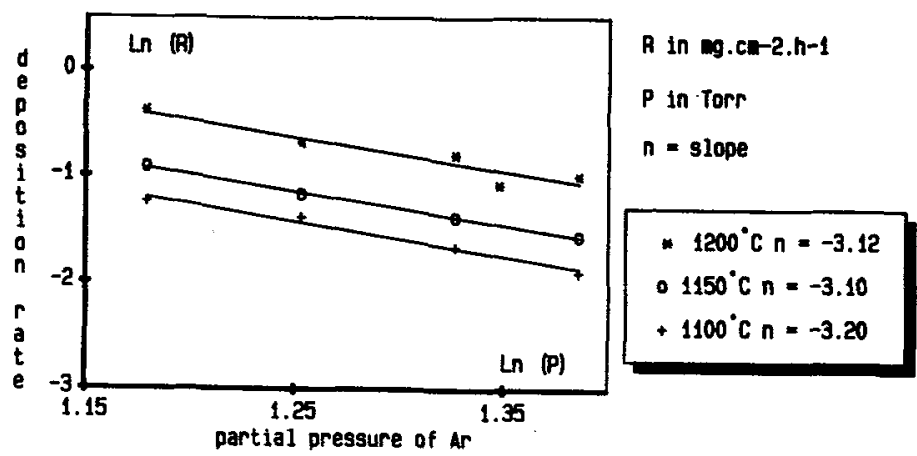

A
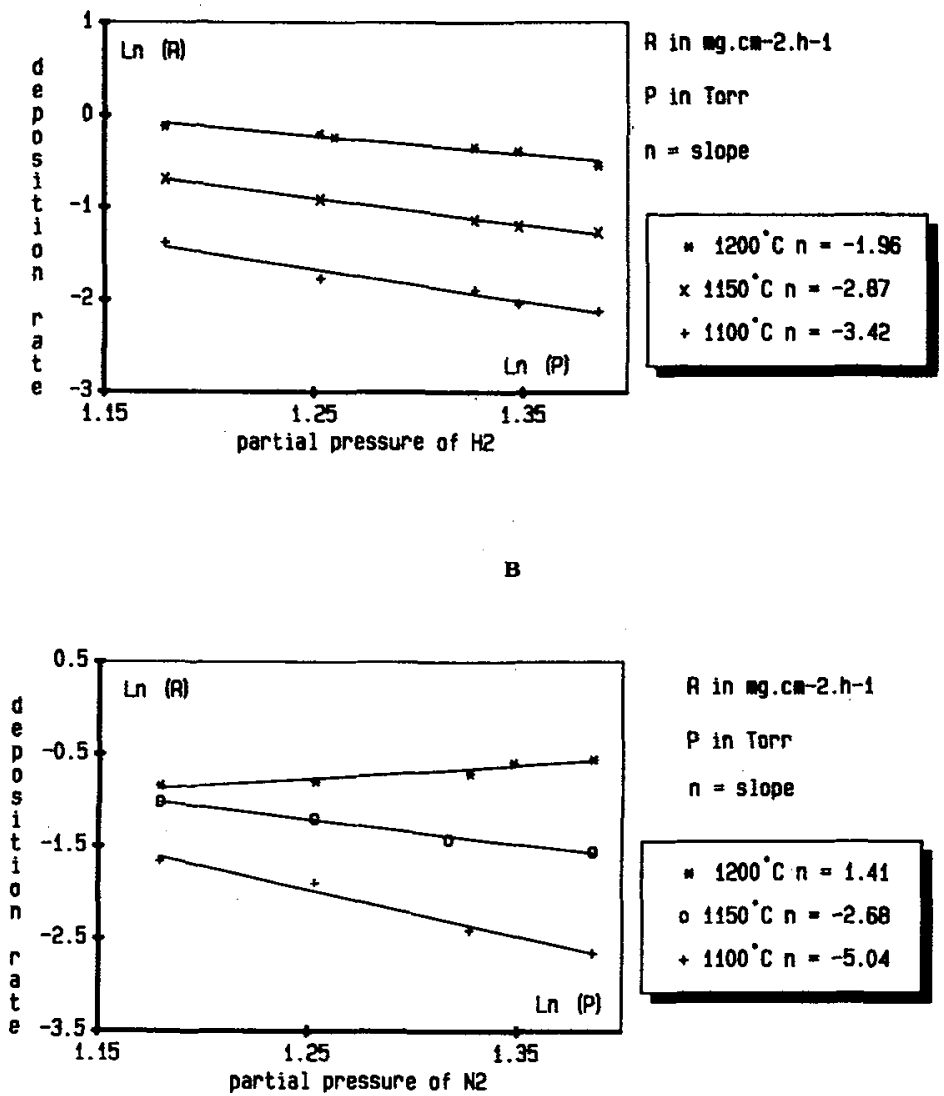

C

Fig. 8 - Growth rate dependency upon partial pressures of diluent gases.
$A$ : (Ar)
B : $\left(\mathrm{H}_{2}\right)$
C : $\left(\mathrm{N}_{2}\right)$
$\mathrm{P}_{\text {TMS }}=6,67 \cdot 10^{-3}$ Torr, $\mathrm{P}_{\mathrm{NH}}=6,67 \cdot 10^{-2}$ Torr, $\mathrm{D}_{\text {Total }}=80 \mathrm{1} / \mathrm{h}$ 
surface of the substrate $/ 17,18 /$. In the absence of the knowledge of the actual nature and gas composition in this region, the observed influence of the carrier gases may be an indirect proof of this hypothesis. Indeed, the experimental results (Figs. 7 and 8 ) reveal two main effects:

- physical : the decrease of $R$, observed on Figs 7A and 7B when hydrogen is replaced by nitrogen and argon, may arise from a diminution of the temperature of the gaseous mixture due to concomitant reduction of the thermal conductivity $/ 17 /$;

- chemical : an addition of any carrier gas induces a dilution of the reactants. This effect explains why $R$ diminishes as a function of the partial pressure of argon and independently of the temperature because the exponent $n$ of the corresponding power law is constant (Fig. 8A). On the reverse, the increase of $\mathrm{n}$ as a function of temperature, observed in the case of $\mathrm{H}_{2}$ (Fig. $8 \mathrm{~B}$ ) and $\mathrm{N}_{2}$ (Fig. $8 \mathrm{C}$ ), suggests that these two gases play a direct chemical role. This effect is especially sensible in the case of nitrogen where where $n$ increases fom -5 at $1100^{\circ} \mathrm{C}$ up to 1.4 at $1200^{\circ} \mathrm{C}$.

Therefore the influence of the partial pressure of carrier gases on the deposition rate is complex. However the particular role played by $\mathrm{N}_{2}$ and $\mathrm{H}_{2}$ may originate in an initiation of the reaction within the gas phase. An indirect proof of this hypothesis is given by the dependence of the apparent activation energy on the nature of the carrier gas. For example, the value determined in the present work $(315 \mathrm{~kJ} / \mathrm{mol})$ is significantly higher than the corresponding ones determined in presence of nitrogen $(272 \mathrm{~kJ} / \mathrm{mol}) / 12 /$ or without diluent gas $(167 \mathrm{~kJ} / \mathrm{mol}) / 19 /$.

\section{4 - CONCLUSION}

The effect of the experimental parameters on the deposition rate of $\mathrm{Si}_{3} \mathrm{~N}_{4}$ films has been studied either through a statistical experimental planning or a systematic kinetic investigation. By performing the deposition at relatively 10 pressures $(4<P<10$ torr), low concentrations of silicon precursor in presence of an excess of ammonia $(5<\mathrm{N} / \mathrm{Si}<10)$ and using hydrogen $(80 \mathrm{l} / \mathrm{h})$ as a carrier gas it is possible to minimize the homogeneous nucleation. The experimental results show that the deposition is limited by the surface chemical reaction between 1000 and $1200^{\circ} \mathrm{C}$. In this range the reaction order is zero with respect to $\mathrm{NH}_{3}$ and one with respect to TMS. In addition carrier gases such as hydrogen and nitrogen have a chemical effect suggesting the contribution of homogeneous reactions within the gas phase to the global process. The corresponding $\mathrm{Si}_{3} \mathrm{~N}_{4}$ films are dense, amorphous and contains traces of oxygen and carbon. The next step of this work will concern the optimization of the deposition conditions with respect to the oxidation resistance of the films in order to protect RBSN samples.

\section{ACKONOWLEDGEMENTS}

The authors wish to thank $M$. LAHAYE (university of Bordeaux $I$ ) for AES and microprobe analysis and MM. MARCUS and SIFRE (Ecole de Chimie de Paris) for ESCA analysis

\section{REFERENCES}

/1/ DESMAISON, J., ROCHE, J.L., YOON, K.H. and BILIY, M., Proc. Sixth Euro. CVD, Jerusalem, Israel, Iscar Ltd, (1987) 144.

$12 /$ BELAIR, P., DESMAISON, J. and BIGAY, Y., Proc. Colloquium : New powders, new products in powder metallurgy and special ceramics, Paris, France, Groupe Français de la cerramique et Societé Française de Métallurgie, (1988) C14-1.

/3/ ARMAS, B. and COMBESCURE, C., Proc. Tenth Int. Conf. CVD, Honolulu, U.S.A., The Electrochem. Soc., $87-8$ (1987) 1060 .

$14 /$ PARLIER, M., Proc. Sixth Euro. Conf. CVD, Jerusalem, Israel, Iscar Ltd, (1987) 364.

15/ ANXIONNA2, F., PARLIER, M., RIVIERE, A. and LANCIN, M., Proc. Thirteenth Int. Conf. Science of Ceramics, Orléans, France, Editions de Physique, J. Phys., Fr., 47 (1986) C1-303.

16/ PARLIER, M. and BIND, J. M., Proc. Fifth Euro. Conf. CVD, Uppsala, Sweden, Uppsala University, (1985) 234 .

|7/ LARTIGUE, J.F. and DUCARROIR, M., Proc. Fifth Euro. Conf. CVD, Uppsala, Sweden, Uppsala University, (1985) 432 .

18/ LARTIGUE, J.F. and SIBIEUDE, F., Rev. Int. Hautes Temper, Refract., Fr., 22 (1985) 71.

/9/ LARTIGUE, J.F., DUCARROIR, M. and ARMAS, B., J. Mater. Sci., 19 (1984) 3079.

$110 /$ LARTIGUE, J.F., DUCARROIR, M. and ARMAS, B., Proc. Ninth Int. Conf. CVD, Cincinnati, Ohio, U.S.A., The Electrochem. Soc., 84-6 (1984) 561 . 
111/ LARTIGUE, J.F. and SIBIEUDE, F., Proc. Ninth Int. Conf. CVD, Cincinnati, Ohio, U.S.A., The Electrochem. Soc., 84-6 (1984) 583.

112/ FISHER, H., Z. Phys. Chem. (Leipzig), 252 (1973) 213.

/13/ HEUGHEBAERT,J.C., "Méthodologie expérimentale", INP Toulouse, France.

114/ YI, K.-S. and CHUN, J.S., Proc. Tenth Int. Conf. CVD, Honolulu, U.S.A., The Electrochem. Soc., 87-8 (1987) 570 .

/15/ MOROSANU, C.E., Thin Solid Films, 65 (1980) 171.

/16/ MOROSANU, C.E, and SEGAL, E., Mater. Chem., 7 (1982) 79.

$117 /$ MELLOTTEe, H. and DELBOURgo, R., Bull. Soc. Fr. Céram, n ${ }^{0} 102$ (1974) 65.

118/ YOON, K.H., Thesis, University of Limoges, France, 1986.

119/ PARLIER, M., Thesis, Ecole Nationale des Mines de Paris, France, 1984. 